\title{
Sewage treatment by vermifiltration with synchronous treatment of sludge by earthworms: a low-cost sustainable technology over conventional systems with potential for decentralization
}

\author{
Rajiv K. Sinha · Gokul Bharambe · \\ Uday Chaudhari
}

(C) Springer Science+Business Media, LLC 2008

\begin{abstract}
Earthworms' body works as a 'biofilter' and they have been found to remove the 5 days' $\mathrm{BOD}\left(\mathrm{BOD}_{5}\right)$ by over $90 \%$, COD by $80-90 \%$, total dissolved solids (TDS) by $90-92 \%$, and the total suspended solids (TSS) by $90-95 \%$ from wastewater by the general mechanism of 'ingestion' and biodegradation of organic wastes, heavy metals, and solids from wastewater and also by their 'absorption' through body walls. Earthworms increase the hydraulic conductivity and natural aeration by granulating the clay particles. They also grind the silt and sand particles, increasing the total specific surface area, which enhances the ability to 'adsorb' the organics and inorganic from the wastewater. Intensification of soil processes and aeration by the earthworms enable the soil stabilization and filtration system to become effective and smaller in size. Suspended solids are trapped on top of the vermifilter and processed by earthworms and fed to the soil microbes immobilized in the vermifilter. There is no sludge formation in the process which requires additional expenditure on landfill disposal. This is also an odor-free process and the resulting vermifiltered water is clean and disinfected enough to be reused for farm irrigation and in parks and gardens
\end{abstract}

Keywords Vermifiltration - Vermifilter bed - Biofilter . Stimulate microbial degradation - Odor-free process . Synchronous sludge treatment - Hydraulic retention time .
Hydraulic loading rate $\cdot$ Biological oxygen demand . Chemical oxygen demand · Total dissolved and suspended solids

\section{Introduction}

Nearly $80 \%$ of the water supply used by society returns as municipal wastewater in the sewer system as sewage. Sewage carries hazardous chemicals and very high loadings of organic matter referred as BOD (biological oxygen demand) and COD (chemical oxygen demand) and solids-both dissolved and suspended solids. Sewage has to be treated to reduce the organic loads before discharging into the environment (rivers and oceans) or else the aerobic bacteria there will consume more dissolved oxygen (DO) from the river/ ocean water to decompose this organic materials thereby depleting the DO values. This would seriously affect the survival of all aquatic organisms in the rivers and oceans.

Vermifiltration of wastewater using waste eater earthworms is a newly conceived novel technology. Earthworms' body works as a 'biofilter' and they have been found to remove the 5 days' $\mathrm{BOD}\left(\mathrm{BOD}_{5}\right)$ by over $90 \%$, COD by $80-90 \%$, total dissolved solids (TDS) by $90-92 \%$, and the total suspended solids (TSS) by $90-95 \%$ from wastewater by the general mechanism of 'ingestion' and biodegradation of organic wastes, heavy metals, and solids from wastewater and also by their 'absorption' through body walls. There is no sludge formation in the process which requires additional expenditure on landfill disposal. This is also an odor-free process and the resulting vermifiltered water is clean enough to be reused for farm irrigation and in parks and gardens. They create aerobic conditions in the waste materials by their burrowing actions, inhibiting the action of anaerobic microorganisms 
which release foul-smelling hydrogen sulfide and mercaptans.

Many developing nations cannot afford to construct and maintain costly STPs. They need more options for sewage treatment at low cost. In both developed and developing world, at least for new developments, centralized sewage treatment system may not fulfill sustainable wastewater management requirements in future due to ever-increasing demand. Individual households or a cluster of homes can treat their domestic wastewater at source in a de-centralized manner so as to reduce the burden (BOD \& COD loads) on the sewage treatment plants (STPs) down the sewer system.

\section{Earthworms-the great waste and environmental managers on earth: their ecology and biology}

The earthworms have over 600 million years of experience in waste and environmental management. No wonder then, Charles Darwin called them as the 'unheralded soldiers of mankind,' and the Greek philosopher Aristotle called them as the 'intestine of earth,' meaning digesting a wide variety of organic materials including the waste organics, from earth (Darwin and Seward 1903; Martin 1976).

Earthworms are long, narrow, cylindrical, bilaterally symmetrical, segmented animals without bones. The body is dark brown, glistening, and covered with delicate cuticle. They weigh over 1,400-1,500 mg after 8-10 weeks. On an average, 2,000 adult worms weigh $1 \mathrm{~kg}$ and one million worms weigh approximately 1 ton. Usually the life span of an earthworm is about 3-7 years depending upon the type of species and the ecological situation. Earthworms harbor millions of 'nitrogen-fixing' and 'decomposer microbes' in their gut. They have 'chemoreceptors' which aid in search of food. Their body contains $65 \%$ protein (70-80\% high quality 'lysine rich protein' on a dry weight basis), 14\% fats, $14 \%$ carbohydrates, and 3\% ash (Gerard 1960; ARRPET 2005).

\subsection{Tremendous abilities of ecological adaptation} for survival in harsh environment

Earthworms are burrowing animals and form tunnels by literally eating their way through the soil. The distribution of earthworms in soil depends on factors like soil moisture, availability of organic matter, and $\mathrm{pH}$ of the soil. They occur in diverse habitats specially those which are dark and moist. Earthworms are generally absent or rare in soil with a very coarse texture and high clay content or soil with $\mathrm{pH}<4$ (Gunathilagraj 1996). Earthworms are also tolerant to moderate salt salinity in soil, but some species like the tiger worms (Eisenia fetida) has been found to be highly salt tolerant. In a study made by Kerr and Stewart (2006) at the US Department of Energy it was found that replicates', with a salt concentration of $15 \mathrm{~g} / \mathrm{kg}$ of soil, survival ranged from $80-100 \%$. This means that E. fetida can tolerate soils nearly half as salty as seawater (Average seawater salinity is around $35 \mathrm{~g} / \mathrm{l}$ ).

Earthworms can also tolerate toxic chemicals in environment. After the Seveso chemical plant explosion in 1976 in Italy, when a vast area was contaminated with extremely toxic chemical like TCDD (2,3,7,8-tetrachlorodibenzo- $p$-dioxin) several fauna perished except for some species of the earthworms that survived. Earthworms which ingested TCDD contaminated soils were shown to bioaccumulate dioxin in their tissues and concentrate it on average 14.5 fold (Satchell 1983). E. fetida also survived $1.5 \%$ crude oil containing several toxic organic pollutants (OECD 2000; Safwat et al. 2002). Earthworms can also tolerate high concentrations of heavy metals in the environment. Some species have been found to bioaccumulate up to $7600 \mathrm{mg}$ of lead $(\mathrm{Pb}) / \mathrm{gm}$ of the dry weight of their tissues (Ireland 1983).

As worms breathe through their skin proper ventilation of air in soil medium is necessary. They can tolerate a temperature range between 5 and $29^{\circ} \mathrm{C}$. A temperature of $20-25^{\circ} \mathrm{C}$ and a moisture of $60-75 \%$ are optimum for good worm function (Hand 1988). Generally earthworms can also tolerate extensive water loss by dehydration (Roots 1956).

\subsection{Enormous power of reproduction and rapid rate of multiplication}

Earthworms are bisexual animals and multiply very rapidly. After copulation each worm ejects lemon-shaped 'cocoon' where sperms enter to fertilize the eggs. Up to 3 cocoons per worm per week are produced. From each cocoon about 10-12 tiny worms emerge. Studies indicate that they double their number at least every 60-70 days. Given the optimal conditions of moisture, temperature, and feeding materials earthworms can multiply by $2^{8}$, i.e. 256 worms every 6 months from a single individual. Each of the 256 worms multiplies in the same proportion to produce a huge biomass of worms in a short time. The total life cycle of the worms is about 220 days. They produce 300-400 young ones within this life period (Hand 1988). A mature adult can attain reproductive capability within 8-12 weeks of hatching from the cocoon. Red worms takes only 4-6 weeks to become sexually mature (ARREPT 2005). Earthworms continue to grow throughout their life.

2.3 Behavioral studies: sensitive to light, touch and dryness

Earthworms are very sensitive to touch, light, and dryness. Cold (low temperature) is not a big problem for them as the 
heat (high temperature). Their activity is significantly slowed down in winter, but heat can kill them instantly. It seems worms are not very sensitive to offensive smell as they love to live and feed on cattle dung and even sewage sludge. However, offensive smell can persist only for a short while in any environment where worms are active. They arrest all odor problems by killing anaerobes and pathogens that create foul odur.

\section{Earlier studies on vermifiltration of sewage}

A pilot study on vermifiltration of sewage was made by Xing et al. (2005) at Shanghai Quyang Wastewater Treatment Facility in China. The earthworm bed which was $1 \mathrm{~m}$ (long) $\times 1 \mathrm{~m}$ (wide) $\times 1.6 \mathrm{~m}$ (high), was composed of granular materials and earthworms. The worm's number was kept at about 8,000 worms/sqm. The average chemical oxygen demand (COD) value of raw sewage used was $408.8 \mathrm{mg} / \mathrm{l}$, that of 5 days biological oxygen demand $\left(\mathrm{BOD}_{5}\right)$ was $297 \mathrm{mg} / \mathrm{l}$ and, that of suspended solids (SS) was $186.5 \mathrm{mg} / \mathrm{l}$. The hydraulic retention time varied from 6 to $9 \mathrm{~h}$ and the hydraulic loading from 2.0 to $3.0 \mathrm{~m}^{3} /\left(\mathrm{m}^{2} . \mathrm{d}\right)$ of sewage. The removal efficiency of COD ranged between $81-86 \%$, the $\mathrm{BOD}_{5}$ between $91-98 \%$, and the SS between 97-98\%.

Gardner et al. (1997) studied on-site effluent treatment by earthworms and showed that it can reduce the BOD and COD loads significantly. Taylor et al. (2003) studied the treatment of domestic wastewater using vermifilter beds and concluded that worms can reduce BOD and COD loads as well as the TDSS (total dissolved and suspended solids) significantly by more than $70-80 \%$. Hartenstein and Bisesi (1989) studied the use of earthworms for the management of effluents from intensively housed livestock which contain very heavy loads of BOD, TDSS, and nutrients nitrogen $(\mathrm{N})$ and phosphorus $(\mathrm{P})$. The worms produced clean effluents and also nutrient-rich vermicompost. Bajsa et al. (2003) also studied the vermifiltration of domestic wastewater using vermicomposting worms with significant results.

\section{The mechanism of worm action in vermifiltration system of sewage}

Earthworms are versatile waste eaters and decomposers. It promotes the growth of 'beneficial decomposer bacteria' in wastewater and acts as an aerator, grinder, crusher, chemical degrader, and a biological stimulator (Dash 1978; Sinha et al. 2002).

(1) The two processes-microbial process and vermiprocess simultaneously work in the vermifiltration system. Earthworms further stimulate and accelerate microbial activity by increasing the population of soil microorganisms and also through improving aeration (by burrowing actions) (Binet et al. 1998). Earthworms hosts millions of decomposer (biodegrader) microbes in their gut and excrete them in soil along with nutrients nitrogen $(\mathrm{N})$ and phosphorus $(\mathrm{P})$ in their excreta called 'vermicast' (Singleton et al. 2003). The nutrients $\mathrm{N}$ and $\mathrm{P}$ are further used by the microbes for multiplication and vigorous action. Edward and Fletcher (1988) showed that the number of bacteria and 'actinomycetes' contained in the ingested material increased up to 1,000 fold while passing through the gut. A population of worms numbering about 15,000 will in turn foster a microbial population of billions of millions (Morgan and Burrows 1982). Singleton et al. (2003) also studied the bacterial flora associated with the intestine and vermicasts of the earthworms and found species like Pseudomonas, Mucor, Paenibacillus, Azoarcus, Burkholderia, Spiroplasm, Acaligenes, and Acidobacterium which has potential to degrade several categories of organics. Acaligenes can even degrade PCBs and Mucor dieldrin).

(2) Vermifilters provide a high specific area-up to $800 \mathrm{sq}$ $\mathrm{m} / \mathrm{gm}$ of soil and voidage up to $60 \%$. Suspended solids are trapped on top of the vermifilter and processed by earthworms and fed to the soil microbes immobilized in the vermifilter (Komarowski 2001).

(3) Dissolved and suspended organic and inorganic solids are trapped by adsorption and stabilized through complex biodegradation processes that take place in the 'living soil' inhabited by earthworms and the aerobic microbes. Intensification of soil processes and aeration by the earthworms enable the soil stabilization and filtration system to become effective and smaller in size.

(4) Earthworms intensify the organic loadings of wastewater in the vermifilter soil bed by the fact that it granulates the clay particles thus increasing the 'hydraulic conductivity' of the system. They also grind the silt and sand particles, thus giving high total specific surface area, which enhances the ability to 'adsorb' the organics and inorganic from the wastewater passing through it. The vermicast produced on the soil bed also offers excellent hydraulic conductivity of sand (being porous like sand) and also high adsorption power of clay. This is ideal for diluted wastewater like sewage (Bhawalkar 1995).

(5) Earthworms also graze on the surplus harmful and ineffective microbes in the wastewater selectively, prevent choking of the medium and maintain a culture of effective biodegrader microbes to function. 


\section{Critical factors affecting vermifiltration of sewage}

Hydraulic Retention Time (HRT) and Hydraulic Loading Rate (HLR) are two important factors which affect the treatment and quality of treated wastewater.

\subsection{Hydraulic retention time (HRT)}

Hydraulic retention time is the time taken by the wastewater to flow through the soil profile (vermifilter bed) in which earthworms inhabits. It is very essential for the wastewater to remain in the vermifiltration (VF) system and be in contact with the worms for certain period of time. HRT depends on the flow rate of wastewater to the vermifiltration unit, volume of soil profile, and quality of soil used. HRT is very critical, because this is the actual time spent by earthworms with wastewater to retrieve organic mater from it as food. During this earthworms carry out the physical and biochemical process to remove nutrients, ultimately reducing BOD, COD, and the TDSS. The longer the wastewater remains in the system in contact with earthworms, the greater will be the efficiency of vermiprocessing and retention of nutrients. Hence the flow of wastewater in the system is an important consideration as it determines the retention of suspended organic matter and solids (along with the chemicals adsorbed to sediment particles). Maximum HRT can results from 'slower rate of wastewater discharge' on the soil profile (vermifilter bed) and hence slower percolation into the bed. Increasing the volume of soil profile can also increase the HRT. The number of live adult worms, functioning per unit area in the vermifilter (VF) bed can also influence HRT.

HRT of vermifiltration system can be calculated as:

HRT $=\left(\rho \times V_{\mathrm{s}}\right) / Q_{\text {wastewater }}$

where $\quad$ HRT $=$ Theoretical hydraulic retention time (hours); $V_{\mathrm{s}}=$ volume of the soil profile (vermifilter bed), through which the wastewater flows and which have live earthworms (cum); $\rho=$ Porosity of the entire medium (gravel, sand, and soil) through which wastewater flows; $Q_{\text {wastewater }}=$ Flow rate of wastewater through the vermifilter bed (cum/h). Thus the hydraulic retention time (HRT) is directly proportional to the volume of soil profile and inversely proportional to the rate of flow of wastewater in the vermifilter bed.

\subsection{Hydraulic loading rate (HLR)}

The volume and amount of wastewater that a given vermifiltration (VF) system (measured in area and depth of the soil medium in the vermifilter bed in which the earthworms live) can reasonably treat in a given time is the hydraulic loading rate of the vermifilter (VF) system. HLR can thus be defined as the volume of wastewater applied, per unit area of soil profile (vermifilter bed) per unit time. It critically depends upon the number of live adult earthworms functioning per unit area in the vermifilter bed. The size and health of the worms is also critical for determining the HLR.

HLR of vermi-filtration system can be calculated as:

$\mathrm{HLR}=V_{\text {wastewater }} /(A \times t)$

where HLR $=$ Hydraulic loading rate $(\mathrm{m} / \mathrm{h}) ; V_{\text {wastewa- }}$ ter $=$ Volumetric flow rate of wastewater (cum); $A=$ Area of soil profile exposed (sqm); $t=$ Time taken by the wastewater to flow through the soil profile (h).

High hydraulic loading rate leads to reduced hydraulic retention time (HRT) in soil and could reduce the treatment efficiency. Hydraulic loading rates will vary from soil to soil. The infiltration rates depend upon the soil characteristics defining pore sizes and pore size distribution, soil morphological characteristics, including texture, structure, bulk density, and clay mineralogy.

\section{Materials and methods}

\subsection{Earthworm species used}

Long-term researches into vermiculture have indicated that the Tiger Worm (Eisenia fetida), Red Tiger Worm (E. andrei), the Indian Blue Worm (Perionyx excavatus), the African Night Crawler (Eudrilus euginae), and the Red Worm (Lumbricus rubellus) are best suited for vermitreatment of variety of solid and liquid organic wastes under all climatic conditions (Graff 1981). Eisenia fetida and $E$. andrei are closely related. An army of the above five species combined together works meticulously.

Our study has indicated that E. fetida, P. excavatus, and $E$. euginae are voracious waste eaters and biodegraders. We used mixture of these three species in our experiment. They are richly available in Queensland, Australia.

\subsection{Raw sewage: characteristics and the acceptable} values

The raw sewage was obtained from the Oxley Wastewater Treatment Plant in South Brisbane.

Sewage is the cloudy fluid of human fecal matter and urine, rich in minerals and organic substances. Water is the major component (99\%) and solid suspension amounts to only $1 \%$. The biochemical oxygen demand (BOD), chemical oxygen demand (COD), and the oxygen consumption (OC) values are extremely high demanding more oxygen by aerobic microbes for biodegradation of organic matter. Dissolved oxygen (DO) is greatly depleted. The nitrogen $(\mathrm{N})$ and phosphorus $(\mathrm{P})$ contents are very high and there are 
heavy metals like cadmium $(\mathrm{Cd})$ and significant amount of coliform bacteria. The total suspended solids (TSS) are also very high.

The average BOD value of the raw sewage ranged between 200 and $400 \mathrm{mg} / \mathrm{l}$, COD ranged between 116 and $285 \mathrm{mg} / \mathrm{l}$, the TSS ranged between 300 and $350 \mathrm{mg} / \mathrm{l}$, and the $\mathrm{pH}$ ranged between 6.9 and 7.3. There is great fluctuation in these values depending upon catchment area, flow rate, and season. Sewage from industrial areas can have high COD values, very low or high $\mathrm{pH}$, due to accidental mixing of industrial wastewater. The normal acceptable values for BOD in treated wastewater is $1-15 \mathrm{mg} / 1$, COD is 60-70 mg/l, TSS 20-30 mg/l, and $\mathrm{pH}$ around 7.0.

\subsection{Experimental study at Griffith University, Brisbane}

\subsubsection{The vermifilter kit and the formation of vermifilter bed}

The pilot study was carried out in a vermiculture kit located in PC2 lab of Griffith University. The temperature in lab was maintained at $21.5^{\circ} \mathrm{C}$, with $50 \%$ humidity. The VC kit contained about 30-40 kg of gravels with a layer of garden soil on top. This formed the vermifilter bed. It has provisions to collect the filtered water at the bottom in a chamber which opens out through a pipe fitted with tap. Above the chamber lies the net of wire mesh to allow only water to trickle down while holding the gravels above. The bottommost layer is made of gravel aggregates of size $7.5 \mathrm{~cm}$ and it fills up to the depth of $25 \mathrm{~cm}$. Above this lies the aggregates of 3.5-4.5 cm sizes filling up to another $25 \mathrm{~cm}$. On the top of this is the 20-cm layer of aggregates of 10-12 mm sizes mixed with sand. The topmost layer of about $10 \mathrm{~cm}$ consists of pure soil in which the earthworms were released. The worms were given around one week settling time in the soil bed to acclimatize in the new environment. As the earthworms play the critical role in wastewater purification their number and population density (biomass) in soil, maturity, and health are important factors. This may range from several hundreds to several thousands. There are reports about 8-10,000 numbers of worms per cubic meter of the worm bed and in quantity (biomass) as $10 \mathrm{~kg}$ per cubic meter (cum) of soil for optimal function (Komarowski 2001). However, in this experiment we started with 500 worms in 0.025 cum of soil bed, which comes to about 20,000 worms per cum of soil. This means even lesser number of worms could have done the job.

\subsubsection{The control kit without earthworms: comparison to assess the precise role of earthworms as biofilters}

A control kit (exact replica of vermifilter kit but devoid of earthworms) was also organized for reference and comparison. It is important to note that the soil and sand particles and the gravels in the kit also contribute in the filtration and cleaning of wastewater by 'adsorption' of the impurities on their surface. They provide ideal sites for colonization by decomposer microbes which work to reduce $\mathrm{BOD}, \mathrm{COD}$, and the TDSS from the wastewater. As the wastewater passes through, a layer of microbial film is produced around them and together they constitute the 'geological' and the 'microbial' (geo-microbial) system of wastewater filtration. With more wastewater passing through the gravels there is more formation of 'biofilms' of decomposer microbes. Hence it is important to have a control kit to determine the precise role of earthworms in the removal of BOD, COD, and the TDSS.

Experiences, however, have shown that the geo-microbial system gets 'choked' after sometimes due to slow deposition of wastewater solids as 'sludge' and becomes un-operational whereas, the vermifiltration system with earthworms continues to operate.

\subsubsection{Parameters studied in sewage vermifiltration}

The untreated sewage that was fed to the vermifilter kit and treated sewage which was collected at the bottom of the kit in a chamber were analyzed to study the biological oxygen demand (BOD), chemical oxygen demand (COD), total suspended solids (TSS), turbidity, and the $\mathrm{pH}$ value. Following standard methods of analysis were adopted (Table 1).

\subsubsection{The experimental procedures}

Around 5-6 L of municipal wastewater were kept in calibrated 10-L capacity PVC drum. These drums were kept on an elevated platform just near the vermifilter kit, as shown in Fig. 1. The PVC drums had tap at the bottom to which an irrigation system was attached. The irrigation system consisted of simple 0.5 -inch polypropylene pipe with holes for trickling water that allowed uniform distribution of wastewater on the soil surface (vermifilter bed). Wastewater from the drums flowed through the irrigation pipes by gravity. The wastewater percolated down through various layers in the vermifilter bed passing through the soil layer inhabited by earthworms, the sandy layer, and the

Table 1 Standard methods adopted to study specified parameters

\begin{tabular}{lll}
\hline SR. No & Description & $\begin{array}{l}\text { Standard } \\
\text { methods }\end{array}$ \\
\hline 1 & Biological Oxygen demand (BOD) & 405.1 \\
2 & Chemical oxygen demand (COD) & $5220 \mathrm{C}$ \\
3 & Total suspended solids (TSS) & 160.2 \\
4 & Turbidity & 180.1 \\
5 & pH & D1293-99 \\
\hline
\end{tabular}




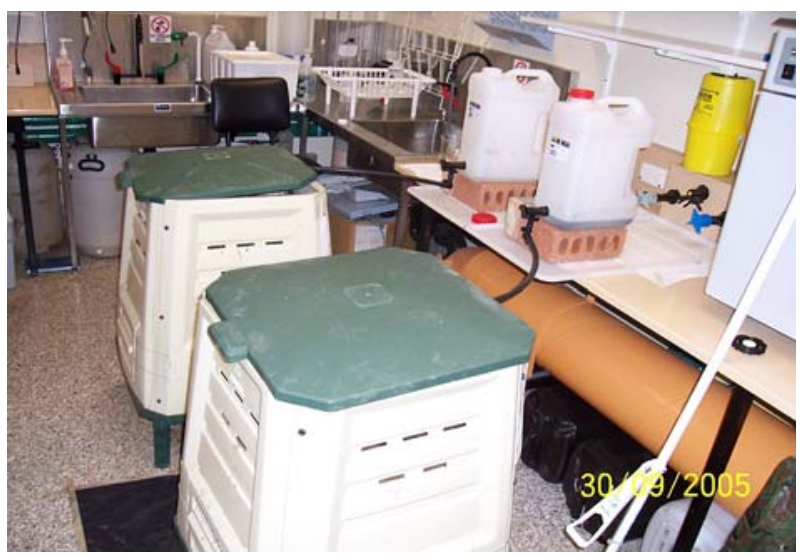

Fig. 1 Vermifilter Kits: regulated flow of wastewater from storage drums determining 1-2 h HRT

gravels, and at the end was collected in a chamber at the bottom of the kit. Next day this treated wastewater from both kits were collected and analyzed for $\mathrm{BOD}_{5}, \mathrm{COD}$, and the TSS. The hydraulic retention time (HRT) was kept uniformly between $1-2 \mathrm{~h}$ in all experiments (Figs. 2-6).

\section{The experimental results and discussion}

\subsection{Important observations}

Both the experimental kits-one with earthworms (vermifilter kit) and the other without (kept as control) were constantly observed for symptoms like foul odor, smooth percolation of wastewater through the soil bed, and appearance of the upper layer of soil bed. The vermifilter kit was also observed and monitored for the agility and movement of the earthworms, its growth, and health conditions. Any toxicity in the wastewater might adversely affect the earthworms' population in the soil bed.

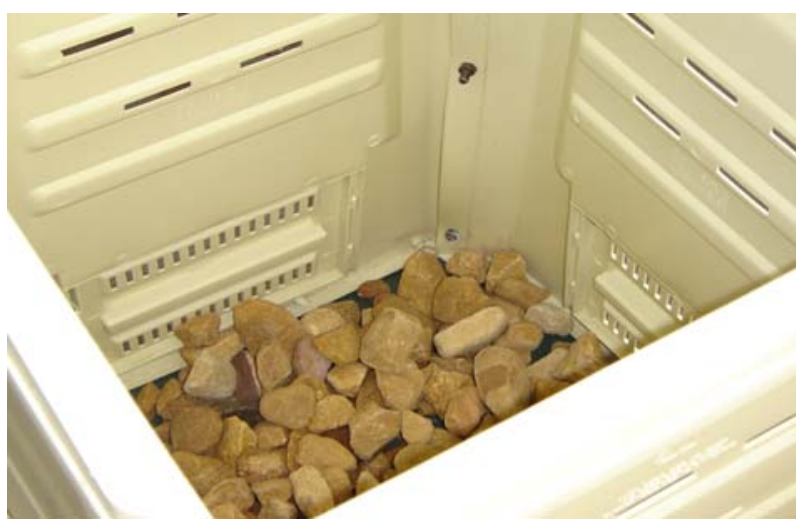

Fig. 2 Different sizes of gravels used in preparation of the vermifilter bed
(1) There was very little or no problem of any foul odor with the vermifilter kit throughout the experimental study. However, foul odor was observed emanating from the control kit.

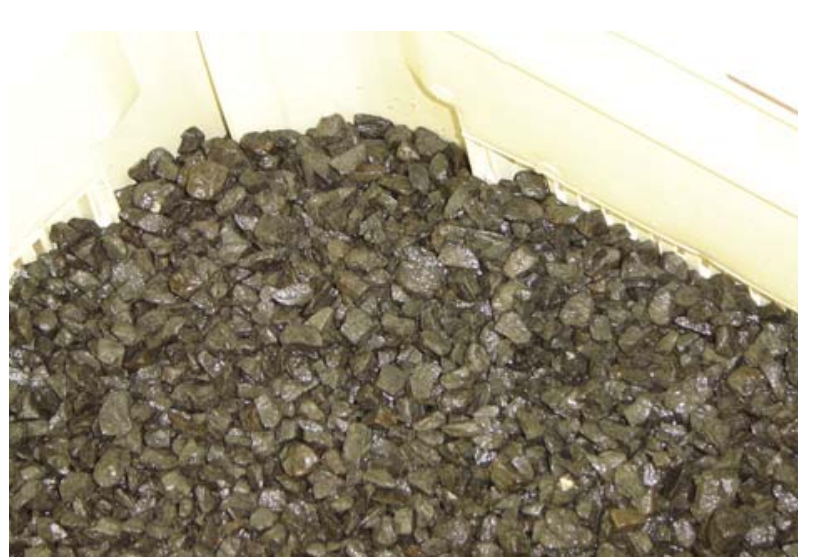

Fig. 3 Different sizes of gravels used in preparation of the vermifilter bed

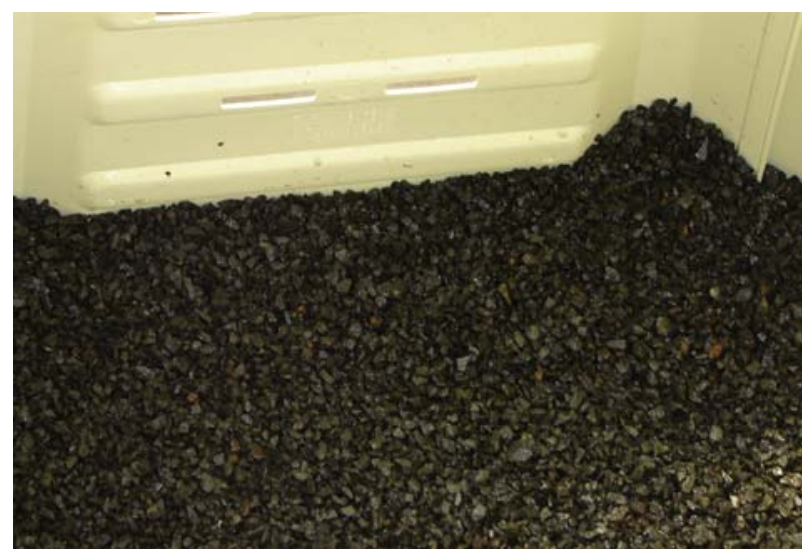

Fig. 4 Different sizes of gravels used in preparation of the vermifilter bed

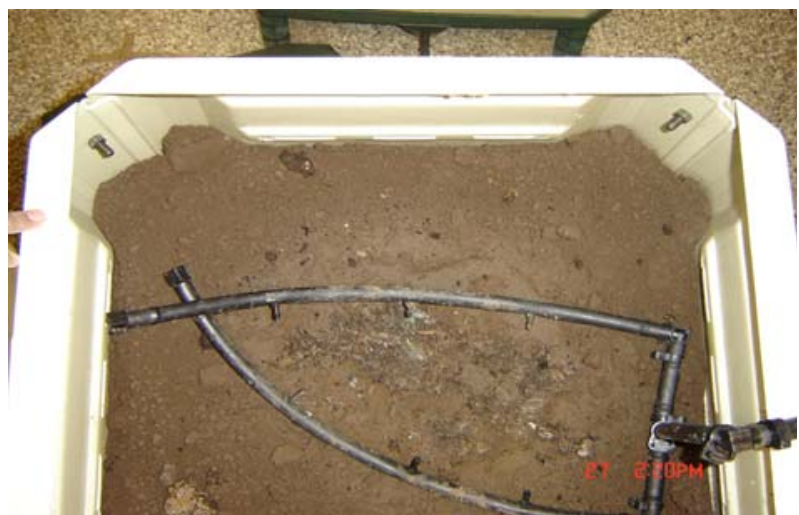

Fig. 5 Soil bed with earthworms and the device of wastewater discharge and distribution through perforated PVC pipes 


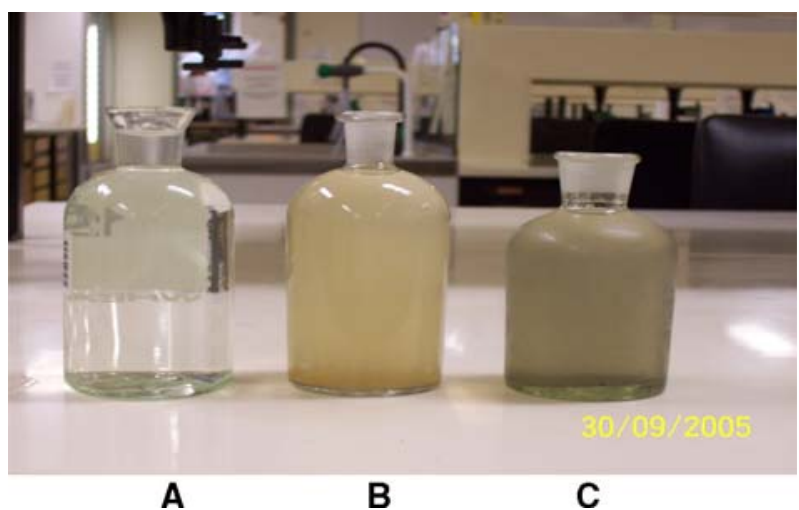

Fig. 6 Appearance of sewage before and after treatment. Bottle A, the clear vermifiltered sewage water; bottle B, the hazy water from the controlled kit; bottle c, The turbid and cloudy sewage water

(2) Wastewater percolated smoothly into the soil bed in the vermifilter kit throughout the experimental study while in the control kit it was constantly 'choking' after few smooth run down of wastewater.

(3) The earthworms in the vermifilter bed were agile and healthy and achieved good growth throughout the period of study. They appeared to be increasing in number and were much developed at the end of the study, after about 14 weeks. Surprisingly several earthworms were seen wriggling down into the sand and gravels and inhabiting in the voids.

\subsection{Improvement in $\mathrm{pH}$ value of treated sewage}

Results indicate that the $\mathrm{pH}$ value of raw sewage is almost neutralized by the earthworms in the vermifilter kit. $\mathrm{pH}$ value of treated sewage without earthworms also improved but it was not consistent in all experiments (Table 2).

\subsection{Removal of TSS}

Results shows that the earthworms can significantly remove the suspended solids from the sewage by over $90 \%$,

Table 2 Improvement in $\mathrm{pH}$ value of municipal wastewater (sewage) treated by earthworms (vermifiltered) and without earthworms (control)

\begin{tabular}{llll}
\hline $\begin{array}{l}\text { Expt. } \\
\text { No }\end{array}$ & $\begin{array}{l}\text { Untreated raw } \\
\text { sewage } \mathrm{pH}\end{array}$ & \multicolumn{2}{l}{ Treated sewage $\mathrm{pH}$} \\
\cline { 3 - 4 } & & $\begin{array}{l}\text { With worms } \\
\text { (vermifiltered) }\end{array}$ & $\begin{array}{l}\text { Without worms } \\
\text { (control) }\end{array}$ \\
\hline 1 & 6.58 & 7.05 & 6.62 \\
2 & 5.76 & 7.35 & 6.05 \\
3 & 6.65 & 7.00 & 7.47 \\
4 & 6.67 & 7.25 & 6.95 \\
5 & 6.05 & 7.06 & 7.15 \\
\hline
\end{tabular}

which in the control kit (where geological and microbial system works together) is over $58 \%$ only (Chaudhary 2006). These solids accumulate over time as 'sludge' and choke the system which ceases to work. However, in the vermifilter kit these solids are constantly eaten up by the earthworms and do not allow any sludge to be formed. This explains why the vermifilter kit do not choke and work smoothly and uninterrupted. Earthworms eat up the solids and also improve the 'adsorption' properties of the geological system (sands and soils) by grinding them in their gizzard (Graph 1, Table 3).

\subsection{Turbidity removal}

Results indicate that the average reduction in turbidity by earthworms is over $98 \%$ while that without earthworms in the control kit is also significantly high and over 97\% (Chaudhary 2006). It appears that the geological system also plays very important role in turbidity removal by 'adsorption' of suspended particles on the surface of the soil, sand and the gravels. Turbidity of treated wastewater is affected by HRT and percent removal of turbidity increases with increase in HRT (Graph 2, Table 4).

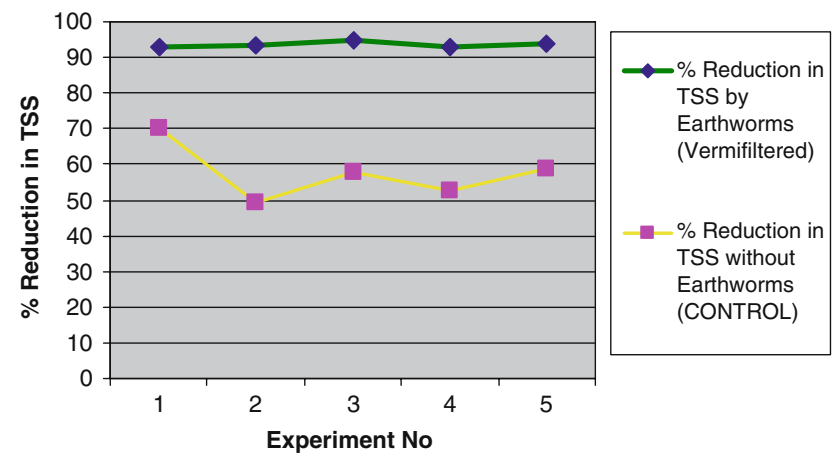

Graph 1 Percentage of reduction in TSS of sewage treated with and without earthworms

Table 3 TSS removal efficiency of sewage treated by earthworms (vermifiltered) and without earthworms (control)) (HRT 1-2 h)

\begin{tabular}{|c|c|c|c|}
\hline \multirow{2}{*}{$\begin{array}{l}\text { Expt. } \\
\text { No }\end{array}$} & \multirow{2}{*}{$\begin{array}{l}\text { Raw untreated } \\
\text { wastewater } \\
(\mathrm{TSS}(\mathrm{mg} / \mathrm{l}))\end{array}$} & \multicolumn{2}{|c|}{ Treated wastewater $(\mathrm{TSS}(\mathrm{mg} / \mathrm{l}))$} \\
\hline & & $\begin{array}{l}\text { With } \\
\text { worms }\end{array}$ & $\begin{array}{l}\text { Without worms } \\
\text { (control) }\end{array}$ \\
\hline 1 & 390 & 28 & 116 \\
\hline 2 & 374 & 24 & 190 \\
\hline 3 & 438 & 22 & 184 \\
\hline 4 & 379 & 27 & 179 \\
\hline 5 & 407 & 25 & 168 \\
\hline
\end{tabular}




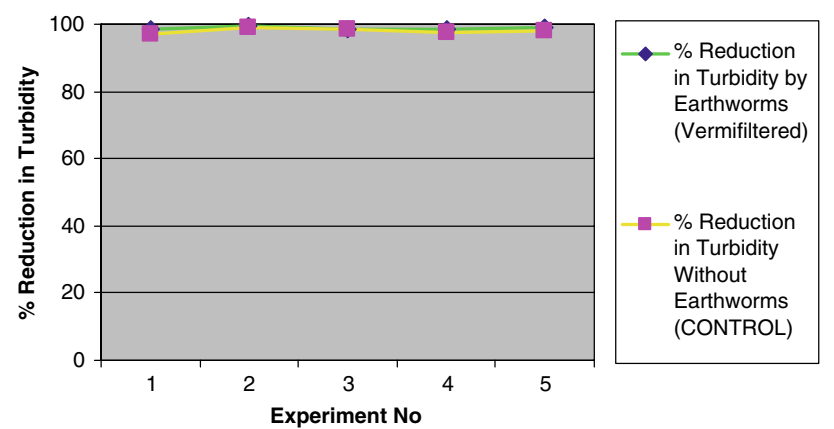

Graph 2 Percentage of reduction in turbidity of sewage treated with and without earthworms

Table 4 Turbidity removal of municipal wastewater (sewage) treated by earthworms (vermifiltered) and without earthworms (control) (HRT: 1-2 h)

\begin{tabular}{|c|c|c|c|}
\hline \multirow{2}{*}{$\begin{array}{l}\text { Expt. } \\
\text { no }\end{array}$} & \multirow{2}{*}{$\begin{array}{l}\text { Untreated raw } \\
\text { sewage turbidity } \\
\text { (NTU) }\end{array}$} & \multicolumn{2}{|c|}{ Treated sewage turbidity (NTU) } \\
\hline & & $\begin{array}{l}\text { With worms } \\
\text { (vermifiltered) }\end{array}$ & $\begin{array}{l}\text { Without worms } \\
\text { (control) }\end{array}$ \\
\hline 1 & 112 & 1.5 & 3.6 \\
\hline 2 & 120 & 0.6 & 1.5 \\
\hline 3 & 74 & 1.1 & 1.2 \\
\hline 4 & 70 & 1.2 & 1.8 \\
\hline 5 & 100 & 1.1 & 2.0 \\
\hline
\end{tabular}

\subsection{Removal of BOD 5}

Results show that the earthworms can remove $\mathrm{BOD}\left(\mathrm{BOD}_{5}\right)$ loads by over $98 \%$ or nearly complete at hydraulic retention time (HRT) of 1-2 h (Chaudhary 2006). BOD removal in the control kit (where only the geological and microbial system works) is just around $77 \%$. Significantly, the earthworms degrade the wastewater organics by 'enzymatic actions' (which work as biological catalysts bringing pace and rapidity in biochemical reactions) and this is the reason for high BOD removal. That is the difference between microbial degradation and vermidegradation (Graph 3, Table 5).
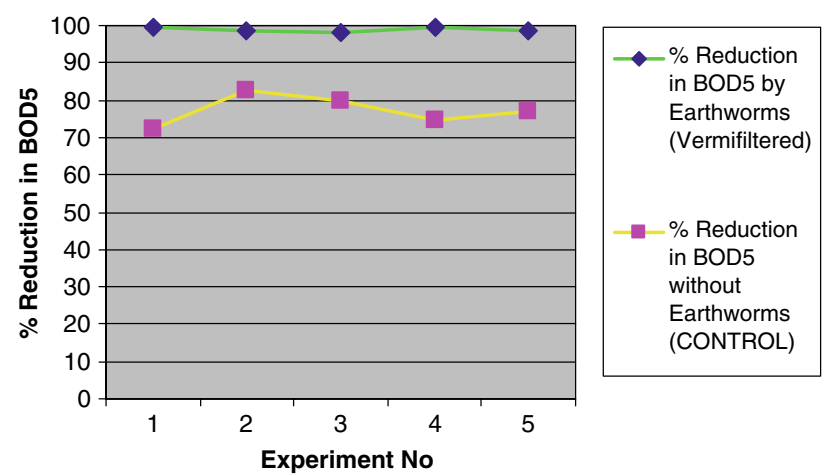

Graph 3 Percentage of reduction in $\mathrm{BOD}_{5}$ of sewage treated with and without earthworms
Table $5 \mathrm{BOD}_{5}$ removal of municipal wastewater (sewage) treated by earthworms (vermifiltered) and without earthworms (control) (HRT: $1-2 \mathrm{~h}$ )

\begin{tabular}{|c|c|c|c|}
\hline \multirow{2}{*}{$\begin{array}{l}\text { Expt. } \\
\text { no }\end{array}$} & \multirow{2}{*}{$\begin{array}{l}\text { Untreated raw } \\
\text { sewage } \\
\left(\mathrm{BOD}_{5}(\mathrm{mg} / \mathrm{l})\right)\end{array}$} & \multicolumn{2}{|c|}{ Treated sewage $\left(\mathrm{BOD}_{5}(\mathrm{mg} / \mathrm{l})\right)$} \\
\hline & & $\begin{array}{l}\text { With worms } \\
\text { (vermifiltered) }\end{array}$ & $\begin{array}{l}\text { Without worms } \\
\text { (control) }\end{array}$ \\
\hline 1 & 309 & 1.97 & 86.3 \\
\hline 2 & 260 & 4.00 & 45.8 \\
\hline 3 & 316 & 6.02 & 63.3 \\
\hline 4 & 328 & 2.06 & 83.2 \\
\hline 5 & 275 & 4.25 & 63.5 \\
\hline
\end{tabular}

\subsection{Removal of COD}

Results show that the average COD removed from the sewage by earthworms is over $45 \%$ while that without earthworms (only the geological and microbial system in the control kit) is just over 18\% (Chaudhary 2006). COD removal by earthworms is not as significant as the BOD, but at least much higher than the microbial system. Again, the enzymes in the gut of earthworms help in the degradation of several of those chemicals which otherwise cannot be decomposed by microbes (Graph 4, Table 6).

\section{Significance and advantages of vermifiltration technology over conventional systems of sewage treatment}

Vermifiltration system of sewage treatment is low energy dependent and has distinct advantage over all the conventional biological wastewater treatment systems- the 'Activated Sludge Process,' 'Trickling Filters,' and 'Rotating Biological Contactors' which are highly energy intensive, costly to install and operate, and do not generate any income. Since the conventional technologies are mostly the flow processes and have finite hydraulic retention time (HRT) it always results into a 'residual stream' of complex

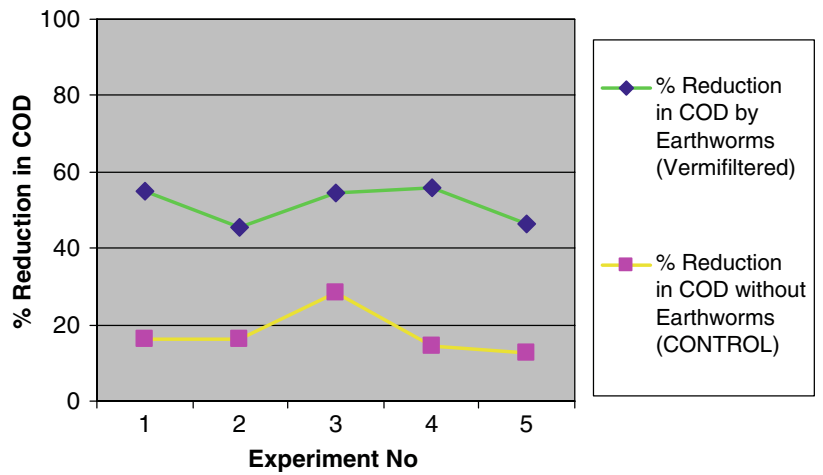

Graph 4 Percentage of reduction in COD of sewage treated with and without earthworms 
Table 6 COD removal of municipal wastewater (sewage) treated by earthworms (vermifiltered) and without earthworms (control) (HRT: $1-2 \mathrm{~h})$

\begin{tabular}{|c|c|c|c|}
\hline \multirow{2}{*}{$\begin{array}{l}\text { Expt. } \\
\text { No }\end{array}$} & \multirow{2}{*}{$\begin{array}{l}\text { Untreated raw } \\
\text { sewage } \\
(\mathrm{COD}(\mathrm{mg} / \mathrm{l}))\end{array}$} & \multicolumn{2}{|c|}{ Treated sewage $(\mathrm{COD}(\mathrm{mg} / \mathrm{l}))$} \\
\hline & & $\begin{array}{l}\text { With worms } \\
\text { (vermifiltered) }\end{array}$ & $\begin{array}{l}\text { without worms } \\
\text { (control) }\end{array}$ \\
\hline 1 & 293 & 132 & 245 \\
\hline 2 & 280 & 153 & 235 \\
\hline 3 & 280 & 128 & 201 \\
\hline 4 & 254 & 112 & 217 \\
\hline 5 & 260 & 139 & 227 \\
\hline
\end{tabular}

organics and heavy metals (while only the simple organics are consumed) in the 'sludge' that needs further treatment (requiring more energy) before landfill disposal. This becomes unproductive. In the vermifilter process there is $100 \%$ capture of organic materials, the capital and operating costs are less, and there is high value added end product (vermicompost).

\subsection{Vermifiltration is low energy system}

Some energy may be required in pumping the wastewater to the vermifiltration unit if gravity flow is not adequate.

\subsection{Synchronous treatment of wastewater and the solids: end products become useful resource for agriculture and horticulture}

Earthworms decompose the organics in the wastewater and also devour the solids synchronously and ingest the heavy metals from both mediums. It works as a 'sludge digester' where the sludge is softened by the grume excreted in the 'mouth' of the earthworms. In the esophagus it is neutralized by calcium $(\mathrm{Ca})$ and then it comes to the intestine where it is absorbed and decomposed by the enzymes. This stabilized sludge is discharged in the vermifilter bed as 'excreta' (vermicompost) which is useful soil additive for agriculture and horticulture (Huges et al. 2005).

\subsection{Vermifiltered sewage is free of pathogens}

Earthworms devour on all the pathogens (bacteria, fungus, protozoa, and nematodes) found in both the wastewater and the sludge as they are their loved food. They also secrete a celeomic fluid which has 'anti-bacterial' properties and arrest the formation of all microbes that cause rotting (Pierre et al. 1982). Some bacteria and fungi fostered by the worms also produce 'antibiotics' which kills the pathogenic organisms in the waste biomass making the medium virtually sterile and odorless. Fungus Pencillium spp. producing antibiotics 'penicillin' has been reported from the intestine of earthworms. The removal of pathogens, fecal coliforms (E. coli), Salmonella spp., enteric viruses, and helminth ova from sewage and sludge appear to be much more rapid when they are processed by E. fetida. Of all E. coli and Salmonella are greatly reduced (Bajsa et al. 2003).

\subsection{Vermifiltered sewage is free of toxic chemicals (heavy metals and also endocrine disrupting chemicals)}

Earthworms have been shown to bioaccumulate high concentrations of toxic chemicals including heavy metals and also the 'endocrine disrupting chemicals' (EDCs) from sewage without affecting their physiology and this particularly when the metals are mostly non-bioavailable. They readily bioaccumulate cadmium $(\mathrm{Cd})$, mercury $(\mathrm{Hg})$, lead $(\mathrm{Pb})$ copper $(\mathrm{Cu})$, manganese $(\mathrm{Mn})$, calcium $(\mathrm{Ca})$, iron $(\mathrm{Fe})$, and zinc $(\mathrm{Zn})$. Some metals are bound by a protein called 'metallothioneins.' The chloragogen cells in earthworms appear to mainly accumulate heavy metals absorbed by the gut.

Markman et al. (2007) have reported significantly high concentrations of EDCs (dibutylphthalate, dioctylphthalate, bisphenol-A and $17 \beta$-estrdiol) in tissues of earthworms (E. fetida) living in sewage percolating filter beds and also in garden soil. Several studies have found that earthworms can also either accumulate or degrade 'organochlorine pesticide' and 'polycyclic aromatic hydrocarbons' (PAHs) residues in the medium in which it feeds (Ireland 1983).

\subsection{Vermifilter treatment of sewage is an odorless system}

There is no foul odor as the earthworms arrest rotting and decay of all putrescible matters in the wastewater and the sludge. They also create aerobic conditions in the soil bed and the waste materials by their burrowing actions, inhibiting the action of anaerobic microorganisms which release foul-smelling hydrogen sulfide and mercaptans.

\subsection{Vermicast-a nutritive plant food}

Earthworms are assuming great economic and ecological value these days in agriculture and horticulture (for improving soil fertility and as live biofertilizer). The worm excreta (vermicast) in the vermifilter bed are a nutritive plant food. They are rich in nutrients NKP. Xing et al. (2005) reported $1.16 \%$ nitrogen, $1.22 \%$ phosphorus, and $1.34 \%$ potassium in the earthworm feces. The earthworms also secrete polysaccharides, proteins, and other nitrogenous compounds. They mineralize the nitrogen $(\mathrm{N})$ in the sewage to make it bioavailable to plants as nutrients (nitrates). They ingest $\mathrm{N}$ and excrete it in the mineral form 
as ammonium and mucoproteins. The ammonium in the soil is biotransformed into nitrates (Bajsa et al. 2003).

\subsection{Production of worm biomass-a protein-rich pro-biotic feed for fishery and poultry}

As the earthworms multiply rapidly with the availability of food (organic matter and microbes) and good moisture conditions (water) both of which are available in plenty in the wastewater a huge population (biomass) of earthworms can result in the process over a period of time. Potentially large quantities of worm biomass will be available as 'probiotic' food for the cattle, poultry, and fish farming, after the first year of vermitreatment. This can be a good source of nutritive 'worm meal' rich in essential amino acids 'lysine' and 'methionine.' It is superior to even 'fish meal.'

\section{Environmental-economics of vermifiltration technology}

Earthworms can physically handle most organic wastewater and potentially at a fraction of the cost of conventional methods of wastewater treatment by sewage treatment plants (STPs). Moreover, STPs are not only an economic but also proving to be an environmental burden due to heavy 'sludge' formation which is a biohazard. Vermifiltration technology by earthworms is a self-promoted; selfregulated; self-improved; self-driven; self-powered, and self-enhanced; very low energy, and less chemical requiring zero-waste technology, easy to construct, operate, and maintain.

Any vermiculture technology involves about $100-1,000$ times higher 'value addition' than other biological technologies. It has less operational cost since it requires energy only for pumping of wastewater and no skilled labor. Maintenance costs are also minimal as it does not involve any mechanical devices (except for pumps). The process has very positive environmental-economics also because of the synchronous treatment of sewage solids (sludge components) within the system and the transformation of the sludge (a biohazard of negative economic value requiring huge cost in safe disposal either by landfill or incineration) into vermi-compost (a nutritive fertilizer of positive economic value) for use in agriculture and horticulture.

Obtaining earthworms from vermiculture farms would be one-time cost in any vermiculture technology as the earthworms multiply rapidly creating huge population of worms which further promote and enhance the process. Furthermore, the technology creates two valuable byproducts. The vermifiltered water is almost crystal clear, nearly, sterile and neutral in $\mathrm{pH}$ fit to be used for non-potable purposes (toilet flush, floor washing, cooling tower make water in industries, etc.). As it also contains useful nutrients it is very suitable for irrigation (gardens, golf courses, fruits and vegetable farms). The resulting 'earthworm biomass' from the process also comes as a very valuable byproduct as pro-biotic nutritive food and would add to the economy of the municipal councils. Vermiculture is a flourishing industry. The cost of approx.500 worms in Australian market is about $\$ 20$.

\section{Commissioning the vermifiltration system of sewage treatment and potential for decentralization}

The real challenge is the commissioning of the vermifiltration technology for sewage treatment in homes. Many developing nations cannot construct and maintain costly STPs. They need more options for sewage treatment at low cost, as they have several other social and developmental priorities with limited resources. Moreover, in the rural and urban communities of both developed and developing world, at least for new developments, centralized sewage treatment system may not fulfill sustainable wastewater management requirements in future due to ever-increasing demand. Individual households or a cluster of homes in cities can also treat their domestic wastewater on-site in a de-centralized manner so as to reduce the burden of BOD and COD loads on the sewage treatment plants (STPs) down the sewer system (Huges et al. 2005).

All the above results were obtained with approximately 500 worms in the vermifilter bed made in about 0.032 cubic meter (cum) of soil. This comes to approximately 16,000 worms per cum of soil. The initial number of worms must have increased substantially over the period of 7-8 weeks of experiment. If a vermifilter bed of 0.3 cum soil is prepared with approximately 5000 worms (over $2.5 \mathrm{~kg}$ ) to start with, it can easily treat $950-1,000 \mathrm{~L}$ of domestic wastewater/sewage generated by (on an average) a family of 4 people with average BOD value ranging between 300-400 mg/l; COD, 100-300 mg/l; TSS, 300$350 \mathrm{mg} / \mathrm{l}$ everyday with hydraulic retention time (HRT) of the wastewater in the vermifilter bed being approximately 1-2 h. Given that the worms multiply and double its number in at least every 60 days under ideal conditions of temperature and moisture, even starting with this number of earthworms a huge population (biomass) of worms with robust vermifiltration system can be established quickly within few months which will be able to treat greater amount of wastewater generated in the family. An important consideration is the peak hour wastewater generation which is usually very high and may not comply with the required HRT (1-2 h) which is very critical for sewage 
treatment by vermi-filtration system. To allow 1-2 h HRT in the vermifilter bed an on-site domestic wastewater storage facility will be required from where the discharge of wastewater to the vermifilter tank can be slowly regulated through flow control.

\section{Conclusion, remarks and recommendations}

Vermifiltration is a logical extension of 'soil filtration' which has been used for 'sewage silviculture' (growing trees) since ancient days. Healthy soil is a biogeological medium acting as an 'adsorbent' of organics, inorganic, pathogens, and parasites. Vermifiltration technology (VFT) can be a most cost-effective and odor-free process for sewage treatment with efficiency, economy, convenience and potential for decentralization. Any wastewater from the households and commercial organizations can be successfully treated by the earthworms and the technology can also be designed to suit a particular wastewater (UNSW ROU 2002). It can treat dilute (less than $0.1 \%$ solids) as well as concentrated wastewater. It has an in-built $\mathrm{pH}$ buffering ability and hence can accept wastewater within a $\mathrm{pH}$ range of 4 to 9 without any pH adjustment (Huges et al. 2007). Though significant removal of BOD, COD, and the TSS is achieved by the microbial-geological system unaided by earthworms as shown from our study in the control kit the system fails to work for longer time as it is frequently choked due to the formation of sludge and colonies of bacteria and fungi (in the vermifilter bed) in the absence of the earthworms which constantly keep devouring on them.

Vermifiltration technology (VFT) by earthworms excels all other 'bio-conversion,, 'bio-treatment' and 'bio-degradation'-technologies by the fact that

1. It can utilize waste organics that otherwise cannot be utilized by other technologies;

2. Achieve greater utilization (rather than the destruction) of waste materials that cannot be achieved by other technologies; and

3. It does all by 'enzymatic actions' and enzymes are biological catalysts giving pace and rapidity to all biochemical reactions even in minute amounts (FraserQuick 2002; Sinha et al. 2007).

It also keeps the system fully aerated with plenty of oxygen available to aerobic decomposer microbes. Aerobic processes are about 10 times faster than the anaerobic. Vermifiltration process driven by the earthworms tends to become more robust and efficient with time as the army of degrader worms grows, proliferating further several battalions of microbial army (aerobic decomposers). It is also a compact biological wastewater treatment system as compared to other non-conventional system such as the 'constructed wetland system' which often suffers from limitations of oxygen for the decomposer aerobic microbes to act efficiently. Wetland-based technologies involve mainly treatment and low utilization of waste materials and hence can be wasteful.

Vermifiltration of any wastewater must be started with higher number of earthworms, at least over 15,000-20,000 worms per cubic meter (cum) of soil in the vermifilter bed for good results. It is also important that they are mostly adult and healthy worms. In vermicomposting of solid waste, which is a continuous process (in days and weeks) the worms have to act 'gradually' in phases while their population (new army of biodegraders) keeps on building up to intensify the biodegradation process. In vermifiltration of wastewater, the worms have to act 'instantly' as the wastewater flows past their body (degrading the organics, ingesting the solids and the heavy metals). That is why the wastewater has to be 'retained' (HRT) in the vermifilter bed for some appropriate period time (which has to be in hours and not in days) while the worms act on the wastewater.

Although the worms have been found to remove very high BOD loads $(10,000-1,00,000 \mathrm{mg} / \mathrm{l}$ often found in wastewater from food-processing industries) within 4 to $10 \mathrm{~h}$ of HRT (Bharambe 2006; Sinha and Bharambe 2007); it can reduce the small BOD loadings of sewage (200$400 \mathrm{mg} / \mathrm{l}$ ) within 30-40 min of HRT. However, in case of municipal wastewater (sewage) treatment the objectives are not only to remove BOD, COD, and TDSS, but also to remove the toxic chemicals including the heavy metals and pathogens from the wastewater. The presence of 'endocrine disrupting chemicals' (EDCs) in sewage which was discovered recently with the development of new instruments are causing great concerns these days. And what is the matter of still greater concern is that they cannot be removed by the conventional sewage treatment methods. They can only be removed by the reverse osmosis methods of 'membrane filtration technology' (MFT) which is costprohibitive at present and all nations cannot afford. The cost-effective vermifiltration technology (VFT) assumes great significance in the removal of EDCs from wastewater. Hence greater hydraulic retention time $(1-2 \mathrm{~h})$ is allowed so that the worms can ingest (bio-accumulate) the toxic chemicals and also devour upon the pathogens completely. Greater interaction with wastewater components also provides better opportunity for the worms to eat all the solids and prevent any sludge formation.

Acknowledgments Authors feel grateful to Professor Roger Braddock former Director of CESR at Griffith University and Professor Bofo Yu Dy. HOS and present Director of CESR, for providing the financial support to carry out the research program. We thank Jane Giffkins and Michelle in the PC 2 lab for providing the laboratory support for analytical studies and Ehrsam Werner for providing space in the PC 2 lab for experimental studies with the vermiculture kits. 
Gokul Bharambe deserves special appreciation for conducting experiments, doing all the calculations and preparing the tables and graphs.

\section{References}

ARRPET (2005) Vermicomposting as an eco-tool in sustainable solid waste management. The Asian Regional Research Program on Environmental Technology, Asian Institute of Technology, Anna University, India

Bajsa O, Nair J, Mathew K, Ho GE (2003) Vermiculture as a tool for domestic wastewater management. Water science and technology. vol 48, no 11-12. IWA Publishing, pp 125-132 (Viewed on 5th May 2006. www.iwaponline.com/wst/04811/wst048110125.htm

Bharambe G (2006) Vermifiltration of wastewater from food processing industries (brewery and milk dairy) in Brisbane. 20 $\mathrm{CP}$ project submitted for the partial fulfillment of the degree of Master in Environmental Engineering, School of Environmental Engineering, Griffith University, Brisbane, June 2006 (Supervisor Dr. Rajiv K. Sinha)

Bhawalkar U (1995) Vermiculture eco-technology. Pub. of Bhawalkar Earthworm Research Institute (BERI), Pune, India

Binet F, Fayolle L, Pussard M (1998) Significance of earthworms in stimulating soil microbial activity. Biol Fertil Soils 27:79-84

Chaudhari U (2006) Vermifiltration of municipal wastewater (sewage) in Brisbane. $20 \mathrm{CP}$ Project submitted for the partial fulfillment of the degree of Master in Environmental Engineering, School of Environmental Engineering, Griffith University, Brisbane, June 2006 (Supervisor Dr. Rajiv K. Sinha)

Darwin F, Seward AC (1903) More letters of Charles Darwin. A record of his work in series of hitherto unpublished letters, vol 2. John Murray, London, 508 pp

Dash MC (1978) Role of earthworms in the decomposer system. In: Singh JS, Gopal B (eds) Glimpses of ecology. India International Scientific Publication, New Delhi, 399-406

Edwards CA, Fletcher KE (1988) Interaction between earthworms and microorganisms in organic matter breakdown. Agri Ecosyst Environ 24:235-247

Fraser-Quick G (2002) Vermiculture - a sustainable total waste management solution. What's New Waste Manag 4(6):13-16

Gardner T, Geary P, Gordon I (1997) Ecological sustainability and onsite effluent treatment systems. Aust J Environ Manage 4:144-156

Gerard BM (1960) The biology of certain British earthworms in relation to environmental conditions, Ph.D. Thesis, University of London

Graff O (1981) Preliminary experiment of vermicomposting of different waste materials using Eudrilus eugeniae Kingberg. In: Appelhof M (ed) Proceedings of the workshop on 'role of earthworms in the stabilization of organic residues'. Malanazoo Pub. Michigan, USA 179-191

Gunathilagraj K (1996) Earthworm: an introduction. Indian council of agricultural research training program; Tamil Nadu Agriculture University, Coimbatore

Hand P (1988) Earthworm biotechnology. In: Greenshields R (ed) Resources and application of biotechnology: the new wave. MacMillan Press Ltd, US

Hartenstein R, Bisesi MS (1989) Use of earthworm biotechnology for the management of effluents from intensively housed livestock. Outlook Agriculture, vol 18. USA, pp 72-76

Hughes RJ, Nair J, Mathew K (2005) The implications of wastewater vermicomposting technologies: on-site treatment systems for sustainable sanitation. WAMDEC conference, Zimbabwe, July 27-30

Hughes RJ, Nair J, Mathew K, Ho G (2007) Toxicity of domestic wastewater $\mathrm{pH}$ to key earthworm species within an innovative decentralised vermifiltration system. Water Sci Technol 55(7):211-218
Ireland MP (1983) Heavy metals uptake in earthworms; earthworm ecology. Chapman \& Hall, London

Kerr M, Stewart AJ (2006) Tolerance test of Elsenia fetida for sodium chloride. US Department of Energy Journal of Undergraduate Research (http://www.scied.science.doe.gov)

Komarowski S (2001) Vermiculture for sewage and water treatment sludges. Water, Publication of Australian Water and Wastewater Association, July, pp 39-43

Markman S, Guschinna IA, Barnsleya S, Buchanana KL, Pascoea D, Mullera CT (2007) Endocrine disrupting chemicals accumulate in earthworms exposed to sewage effluents. Cardiff School of Biosciences, Cardiff University, Cardiff, UK. J Chemosphere 70(1):119-125

Martin JP (1976) Darwin on earthworms: the formation of vegetable moulds. Bookworm Publishing, ISBN 0-916302-06-7

Morgan M, Burrows I (1982) Earthworms/microorganisms interactions. Rothamsted Exp. Stn. Rep

OECD (2000) Guidelines for testing organic chemicals. Proposal for new guidelines: earthworms reproduction tests (E. fetida andrei). Organization for Economic Co-operation and Development (www.oecd.org)

Pierre V, Phillip R, Margnerite L, Pierrette C (1982) Anti-bacterial activity of the haemolytic system from the earthworms Eisinia foetida andrei. Invertebrate Pathology 40:21-27

Roots BI (1956) The water relation of earthworms; ii. resistance to desiccation \& emersion and behavior when submerged and when allowed a choice of environment. J Exper Biol 33:29-44

Safawat H, Hanna S, Weaver RW (2002) Earthworms survival in oil contaminated soil. J Plant and Soil 240:127-132

Satchell JE (1983) Earthworm ecology- from darwin to vermiculture. Chapman and Hall Ltd., London pp 1-5

Singleton DR, Hendrix BF, Coleman DC, Whitemann WB (2003) Identification of uncultured bacteria tightly associated with the intestine of the earthworms Lumricus rubellus. Soil Bio Biochem 35:1547-1555

Sinha RK, Bharambe G (2007) Removal of high BOD and COD loadings of primary liquid waste products from dairy industry by vermifiltration technology using earthworms; Ind J Enviro Prot (IJEP) 27(6):486-501; ISSN 0253-7141; Regd. No. R.N. 40280/ 83; Indian Institute of Technology, BHU, India

Sinha RK, Heart S, Agarwal S, Asadi R, Carretero E (2002) Vermiculture technology for environmental management: study of the action of the earthworms Eisinia foetida, Eudrilus euginae and Perionyx excavatus on biodegradation of some community wastes in India and Australia. The Environmentalist 22(2):261268

Sinha RK, Nair J, Bharambe G, Patil S, Bapat P (2007) Vermiculture revolution: a low-cost \& sustainable technology for management of municipal \& industrial organic wastes (solid \& liquid) by earthworms. Invited Paper by NOVA Science Publishers, NY, USA (Edited book: Waste management: research development \& policy)

Taylor et al (2003) The treatment of domestic wastewater using small-scale vermicompost filter beds. Ecol Eng 21:197-203

UNSW ROU (2002) Best practice guidelines to managing on-site vermiculture technologies. University of New South Wales Recycling Organics Unit, Sydney, NSW, Australia (Viewed on December 2004 www.resource.nsw.gov.au/data/Vermiculture \%20BPG.pdf

Xing M, Yang J, Lu Z (2005) Microorganism-earthworm integrated biological treatment process-a sewage treatment option for rural settlements. ICID 21st European regional conference, 1519 May 2005, Frankfurt; Viewed on 18 April 2006. www.zalf.de/icid/ICID_ERC2005/HTML/ERC2005PDF/ Topic_1/Xing.pdf 